\title{
Імітаційна модель функціонування системи метрологічного обслуговування засобів вимірювального контролю параметрів зразків озброєння та військової техніки на основі мереж Петрі
}

\author{
Андрій Дядечко * 1 А \\ А Національний університет оборони України імені Івана Черняховського, м. Київ, Україна
}

Received: October 9, 2021 | Revised: October 21, 2021 | Accepted: October 30, 2021

DOI: $10.33445 / s d s .2021 .11 .5 .17$

\begin{abstract}
Анотація
На сьогоднішній день, в умовах інтенсивного розвитку озброєння та військової техніки, засобів контролю його параметрів, інформаційних та цифрових технологій, та в умовах поетапного впровадження стандартів НАТО в Збройних Силах України, одним з пріоритетних завдань щодо розвитку Збройних Сил України $\epsilon$ створення ефективних систем забезпечення зразків озброєння, до яких відноситься й система метрологічного обслуговування засобів вимірювального контролю ї параметрів.

Вирішення такого завдання аналітичним шляхом $€$, як правило, складним, а в ряді випадків по суті неможливим. Як наслідок, в наявності велика кількість взаємних зв'язків як між елементами системи, так і між різнорідними засобами вимірювального контролю параметрів всередині кожного елементу.

Проаналізувати та отримати інформацію про структуру та динамічну поведінку системи, оцінити їі та виробити пропозицій щодо ї̈ удосконалення або змінення дозволяють відомі методи імітаційного моделювання.

у зв'язку з цим, для вирішення завдань такого вигляду, в статті запропоновано використовувати теорію мереж Петрі для імітаційного моделювання функціонування системи метрологічного обслуговування засобів вимірювального контролю параметрів зразків озброєння та військової техніки.
\end{abstract}

Ключові слова: метрологічне обслуговування, імітаційне моделювання, мережі Петрі.

\section{Постановка проблеми}

Проведення експериментальних досліджень функціонування складних систем досить складний та трудомісткий процес. Провести такі дослідження з використанням реальних складових системи метрологічного обслуговування засобів вимірювального контролю параметрів зразків озброєння та військової техніки (ОВТ) змінюючи їх структуру, параметри та склад не можливо. Імітаційних моделей за допомогою яких можна провести експериментальне дослідження функціонування системи метрологічного обслуговування засобів вимірювального контролю параметрів зразків ОВТ не розроблено.

\section{Аналіз останніх досліджень та публікацій}

Проведений аналіз попередніх основних складових - підсистеми досліджень показав, що під час проведення метрологічного обслуговування засобів експериментальних досліджень системи вимірювального контролю параметрів метрологічного забезпечення та її однієї з зразків ОВТ, жодним 3 авторів не

\footnotetext{
1 * Corresponding author: ад'юнкт кафедри технічного забезпечення, e-mail: andrewvvs@gmail.com, ORCID: 0000-0003-0191-8326
} 
проводилось дослідження функціонування зазначеної системи [1-6]. В розглянутих роботах авторами використовувались різноманітні методи моделювання для опису системи метрологічного обслуговування засобів вимірювального контролю параметрів зразків ОВТ. Основні з них це методи математичного моделювання, напівмарківські моделі, канонічні моделі. Разом з тим в зазначених публікаціях описуються моделі, які не дозволяють

\section{Постановка завдання}

Для забезпечення якісного проведення робіт 3 метрологічного обслуговування засобів вимірювального контролю параметрів зразків ОВТ необхідно мати раціонально побудовану систему метрологічного обслуговування, яка спроможна ефективно виконувати свої функції. Разом з тим необхідно визначити проводити аналіз динамічної поведінки системи та їі елементів в залежності від параметрів моделювання. Описані попередниками моделі не дозволяють провести моделювання функціонування системи з прив'язкою до модельного часу, що не дозволяє оцінити часові показники роботи системи. Тому необхідно розробити імітаційну модель системи метрологічного обслуговування засобів вимірювального контролю параметрів зразків ОВТ.

\section{Виклад основного матеріалу}

3 розробкою швидкодіючих ПЕОМ використання і користь моделювання значно зросли. Представлення системи математичною моделлю, перетворення цієї моделі в команди для ПЕОМ і виконання програми на ПЕОМ зробили можливим моделювання більших та більш складних систем. Це призвело в результаті до значних досліджень методів моделювання на ПЕОМ. Для розроблення імітаційної моделі функціонування системи метрологічного обслуговування ЗВК параметрів зразків ОВТ в статті використано мережі Петрі.

Мережі Петрі - інструмент дослідження систем. Теорія мереж Петрі робить можливим моделювання системи математичним представленням її у вигляді мережі Петрі. Передбачається, що аналіз мереж Петрі допоможе отримати важливу інформацію про структуру та динамічну поведінку системи, що моделюється. Ця інформація буде корисна для оцінювання системи, що моделюється та вироблення пропозицій щодо її удосконалення або раціональний порядок функціонування зазначеної системи.

Отже, метою статті $€$ обґрунтування імітаційної моделі функціонування системи метрологічного обслуговування засобів вимірювального контролю параметрів зразків ОВТ побудованої з використанням теорії мереж Петрі. змінення [7].

Мережі Петрі застосовуються виключно у моделюванні. у багатьох областях досліджень явище вивчається не безпосередньо, а опосередковано, через модель. Мережі Петрі розроблялись спеціально для моделювання тих систем, які містять взаємодіючі паралельні компоненти, що характерно й для системи метрологічного обслуговування засобів вимірювального контролю параметрів зразків ОВТ. Вперше мережі Петрі запропонував Карл Адам Петрі. у своїй докторській дисертації "Kommunikation mit Automaten" (Зв'язок автоматів) Петрі сформулював основні поняття теорії зв'язку асинхронних компонентів обчислювальної системи. Зокрема, він детально розглянув опис причинних зв'язків між подіями.

Можливі декілька шляхів практичного застосування мереж Петрі під час проектування та аналізу систем. В одному 3 них мережі Петрі розглядаються як допоміжний інструмент аналізу. Тут для 
побудови системи використовуються Для їх усунення необхідно модифікувати загальноприйняті методи проектування. проект. Модифікований проект потім знову Потім побудована система моделюється моделюється та аналізується. Цей цикл мережею Петрі та модель аналізується. Будь повторюється до тих пір, доки результати які складнощі, що зустрічаються під час аналізу не будуть позитивні. Такий підхід аналізу вказують на недосконалості проекту. проілюстрований на рис. 1 [8].

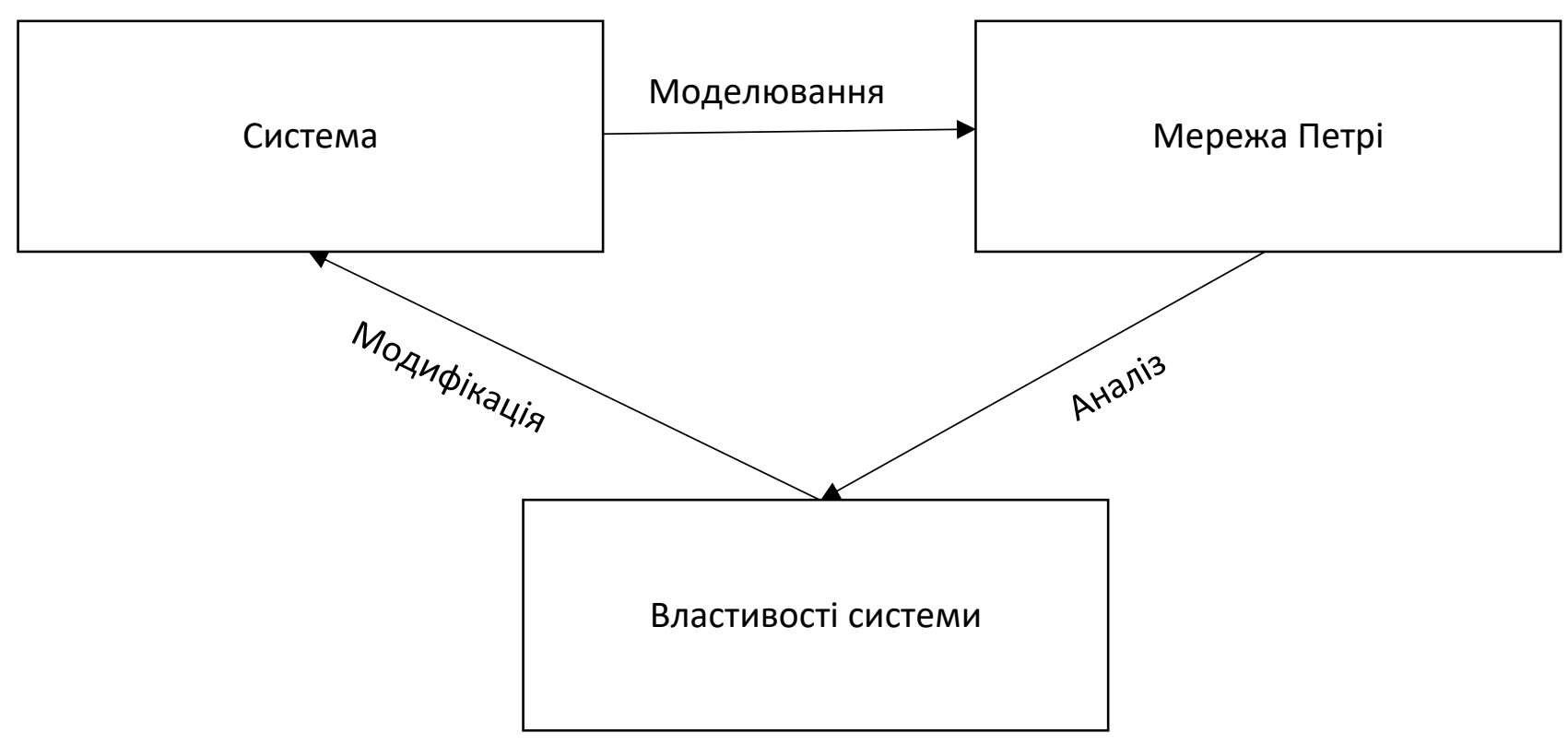

Рисунок 1 - Використання мереж Петрі для моделювання та аналізу систем

Мережа Петрі складається 3 чотирьох елементів: множини позицій $P$, множини переходів $T$, вхідна функція / і вихідна функція O. Вхідна і вихідна функція пов'язані 3 позиціями і переходами. Вхідна функція I відображає перехід $t_{j}$ у множину позицій I $\left(t_{j}\right)$, що називаються вхідними позиціями переходу. Вихідна функція $O$ відображає перехід $t_{j}$ у множину позицій $O\left(t_{j}\right)$, що називаються вихідними позиціями переходу.

Структура мережі Петрі С визначається її позиціями, переходами, вхідною та вихідною функціями. ІІї можна представити виразом [7]

$$
C=(P, T, I, O)
$$

де $P=\left\{p_{1}, p_{2}, \ldots, p_{n}\right\} \quad$ - скінченна множина позицій, $n \geq 0$;

$T=\left\{t_{1}, t_{2}, \ldots, t_{m}\right\}-$ скінченна множина переходів, $m \geq 0$;

множина позицій і множина переходів не перетинаються, $P \cap T=\emptyset$;
$I: T \rightarrow P^{\infty} \quad$ - вхідна функція відображення із переходів в комплекти позицій;

$O: T \rightarrow P^{\infty}$ - вихідна функція відображення із переходів в комплекти позицій.

Потужністю множини $P \in$ число $n$, a потужністю множини $T \in$ число $m$. Довільний елемент $P$ позначається символом $p_{i}, i=1, \ldots, n$, а довільний елемент $T$ - символом $t_{j}, j=1, \ldots, m$.

Позиція $p_{i} \in$ вхідною позицією переходу $t_{j}$ у тому випадку, якщо $p_{i} \in I\left(t_{j}\right)$ і вихідною позицією, якщо $p_{i} \in O\left(t_{j}\right)$. Входи і виходи переходів являють собою комплекти позицій. Комплект являє собою узагальнення множини, в яку включені елементи, які багатократно повторюються - елементи, що тиражуються.

Використання комплектів, а не множин для входів і виходів переходу дозволяє позиції бути кратним входом або кратним виходом переходу [9]. Кратність вхідної 
позиції $p_{i}$ для переходу $t_{j} \in$ число появ позиції у вхідному комплекті переходу \# $\left(p_{i}, I\left(t_{j}\right)\right)$. Аналогічно кратність вихідної позиції $p_{i}$ для переходу $t_{j} \in$ число появ позиції у вихідному комплекті переходу \# $\left(p_{i}, O\left(t_{j}\right)\right)$. Якщо вхідна i вихідна функції $€$ множинами, а не комплектами, то кратність кожної позиції $€$ або 0 , або 1.

В значній мірі теоретична робота по мережам Петрі основана на формальному визначені мереж Петрі, що викладено вище. Проте, разом з тим, для ілюстрації понять теорії мереж Петрі найбільш зручніше графічне представлення мережі Петрі. Теоретико-графовим представленням мережі Петрі $\epsilon$ двочастковий орієнтований мультиграф.

Структура мережі Петрі представляє собою сукупність позицій і переходів. У відповідності до цього граф мережі Петрі має два типи вузлів:

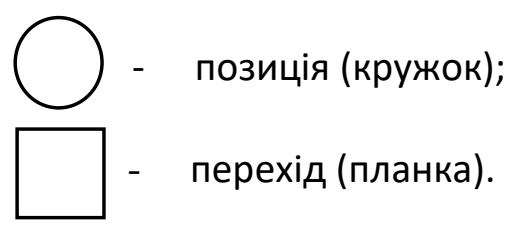

Орієнтовані дуги (стрілки) з'єднують позиції і переходи, при цьому деякі дуги направлені від позиції до переходів, а інші від переходів до позицій. Дуга, що направлена від позиції $p_{i}$ до переходу $t_{j}$ визначає позицію, яка $\epsilon$ входом переходу. Кратні входи в перехід вказуються кратними дугами із вхідних позицій в перехід. Вихідна позиція вказується дугою від переходу до позиції. Кратні виходи також представлені кратними дугами.

Маркування $\mu$ це присвоєння фішок позиціям мережі Петрі. Фішка - це примітивне поняття мереж Петрі (подібно позиціям та переходам). Фішки присвоюються (можна вважати, що вони належать) позиціям. Кількість та положення фішок при виконанні мережі Петрі можуть змінюватись. Фішки використовуються для визначення виконання мережі Петрі.
Маркування $\mu$ мережі Петрі $C=(P, T, I, O) \epsilon$ функція, що відображає множину позицій $P$ у множину невід'ємних цілих чисел $N$.

$$
\mu: P \rightarrow N
$$

Маркування $\mu$ може бути також визначене як $n$-вектор $\mu=\left(\mu_{1}, \mu_{2}, \ldots, \mu_{n}\right)$, де $n=|P|$ i кожне $\mu_{i} \in N, i=1, n$. Вектор $\mu$ визначає для кожної позиції $p_{i}$ мережі Петрі кількість фішок в цій позиції. Кількість фішок в позиції $p_{i} \in \mu_{i}$, $i=1, n$. Зв'язок між визначеннями маркування як функції і як вектору очевидним чином встановлюється співвідношенням

$$
\mu\left(p_{i}\right)=\mu_{i}
$$

Позначення ії̈ у вигляді функції $€$ дещо більш загальним і тому використовується значно частіше.

Промаркована мережа Петрі $M=(C, \mu)$ це сукупність структури мережі Петрі $C$ та маркування $\mu$ і може бути записана у вигляді

$$
M=(P, T, I, O, \mu)
$$

На графі мережі Петрі фішки зображуються маленькою крапкою в кружку, який представляє позицію мережі Петрі.

Так як кількість фішок, яка може бути визначена для кожної позиції, необмежена, то в цілому для мережі Петрі існує нескінченно багато маркувань. Множина всіх маркувань мережі Петрі $3 n$ позиціями $€$ множиною усіх $n$-векторів, $N^{n}$. Ця множина хоч і нескінченна, проте $\epsilon$ злічуваною.

Перехід може запускатися тільки в тому випадку, коли він дозволений. Перехід називається дозволеним, якщо кожна з його вхідних позицій має число фішок що дорівнює числу дуг із позиції в перехід. Кратні фішки необхідні для кратних вхідних дуг. Фішки у вхідній позиції, які дозволяють перехід, називаються його дозволяючими фішками.

Виконанням мережі Петрі управляють кількість та розподіл фішок в мережі. Фішки знаходяться в кружках і управляють виконанням переходів мережі. Мережа Петрі виконується шляхом запусків переходів. Перехід запускається видаленням фішок 3 
його вхідних позицій і утворенням нових фішок, що поміщаються в його вихідні позиції.

Перехід $t_{j} \in T$ в промаркованій мережі Петрі $C$ з маркуванням $\mu$ дозволений, якщо для усіх $p_{i} \in P$

$$
\mu\left(p_{i}\right)>\#\left(p_{i}, I\left(t_{j}\right)\right)
$$

Перехід запускається видаленням всіх дозволяючих фішок з його вхідних позицій та подальшим поміщенням в кожну 3 його вихідних позицій по одній фішці для кожної дуги.

Запуск переходу в цілому змінює маркування $\mu$ мережі Петрі на нове маркування $\mu^{\prime}$. Відмітимо також, що так як можна запустити тільки дозволений перехід, то при запуску переходу кількість фішок в кожній позиції завжди залишається невід'ємною. Запуск переходу ніколи не видалить фішку, що відсутня у вхідній позиції. Якщо будь-яка вхідна позиція переходу не має достатньої кількості фішок, то перехід не дозволений та не може бути запущений.

Перехід $t_{j}$ в промаркованій мережі Петрі з маркуванням $\mu$ може бути запущений завжди, коли він дозволений. В результаті запуска дозволеного переходу $t_{j}$ утворюється нове маркування $\mu^{\prime}$ що визначається наступним співвідношенням

$$
\mu^{\prime}\left(p_{i}\right)=\mu\left(p_{i}\right)-\#\left(p_{i}, I\left(t_{j}\right)\right)+\#\left(p_{i}, O\left(t_{j}\right)\right)
$$

Стан мережі Петрі визначається ії маркуванням [8]. Запуск переходу змінює стан мережі Петрі шляхом зміни маркування мережі. Простір станів мережі Петрі, що має $n$ позицій, $є$ множиною усіх маркувань, тобто $N^{n}$. Зміни стану, що викликані запуском переходу, визначається функцією зміни $\delta$, яку ми назвемо функцією наступного стану. Коли ця функція застосовується до маркування $\mu$ (стану) та переходу $t_{j}$, вона утворює нове маркування (стан), яке утворюється при запуску переходу $t_{j}$ в маркуванні $\mu$. Так як $t_{j}$ може бути запущений тільки в тому випадку, коли він дозволений, то функція $\delta\left(\mu, t_{j}\right)$ не визначена, якщо $t_{j}$ не дозволений в маркуванні $\mu$. Якщо ж $t_{j}$ дозволений, то $\delta(\mu$, $\left.t_{j}\right)=\mu^{\prime}$, де $\mu^{\prime}$ це маркування, отримане в результаті видалення фішок 3 входів $t_{j}$ i додавання фішок у виходи $t_{j}$.

Функція наступного стану для мережі Петрі $C$ з маркуванням $\mu$ та переходом $t_{j} \in T$ записується виразом

$$
\delta: N^{n} \times T \rightarrow N^{n}
$$

Функція $\delta$ визначена тоді і тільки тоді, коли $\mu\left(p_{i}\right) \geq \#\left(p_{i}, I\left(t_{j}\right)\right)$ для усіх $p_{i} \in P$. Якщо $\delta(\mu$, $\left.t_{j}\right)$ визначена, то $\delta\left(\mu, t_{j}\right)=\mu^{\prime}$, де $\mu^{\prime}\left(p_{i}\right)$ визначається за виразом для усіх $p_{i} \in P$

$$
\mu^{\prime}\left(p_{i}\right)=\mu\left(p_{i}\right)-\#\left(p_{i}, I\left(t_{j}\right)\right)+\#\left(p_{i}, O\left(t_{j}\right)\right)
$$

Просте представлення системи мережею Петрі засновано на двох основоположних поняттях: подіях та умовах [9]. Подія - це дія, що має місце в системі. Виникненням подій управляє стан системи. Стан системи може бути описаний множиною умов. Умова - це предикат або логічний опис стану системи. Умова може приймати або значення "істина", або значення "хиба".

Так як події $\epsilon$ діями, то вони можуть відбуватися. Для того щоб подія відбулась, необхідне виконання відповідних умов. Ці умови називаються передумовами події. Виникнення події може викликати порушення передумов та може призвести до виконання інших умов, постумов.

При моделюванні функціонування системи метрологічного обслуговування засобів вимірювального контролю параметрів зразків ОВТ мережа Петрі буде мати структуру С математичне представлення якої буде мати наступний вигляд: 


$$
\begin{array}{cc}
P= & C=(P, T, I, O) \\
P=\left\{p_{a}, p_{b}, p_{c}, p_{d}, p_{e}, p_{f}, p_{g}, p_{h}, p_{i}, p_{j}, p_{k}, p_{l}\right\} \\
T=\left\{t_{1}, t_{2}, t_{3}, t_{4}, t_{5}, t_{6}, t_{7}, t_{8}, t_{9}, t_{10}\right\} \\
I\left(t_{1}\right)=\{0\} & O\left(t_{1}\right)=\left\{p_{a}\right\} \\
I\left(t_{2}\right)=\left\{p_{a}, p_{g}, p_{d}\right\} & O\left(t_{2}\right)=\left\{p_{i}\right\} \\
I\left(t_{3}\right)=\left\{p_{i}\right\} & O\left(t_{3}\right)=\left\{p_{d}, p_{b}, p_{g}\right\} \\
I\left(t_{4}\right)=\left\{p_{a}, p_{h}, p_{d}\right\} & O\left(t_{4}\right)=\left\{p_{j}\right\} \\
I\left(t_{5}\right)=\left\{p_{j}\right\} & O\left(t_{5}\right)=\left\{p_{d}, p_{b}, p_{h}\right\} \\
I\left(t_{6}\right)=\left\{p_{b}, p_{g}, p_{e}\right\} & O\left(t_{6}\right)=\left\{p_{k}\right\} \\
I\left(t_{7}\right)=\left\{p_{k}\right\} & O\left(t_{7}\right)=\left\{p_{g}, p_{c}\right\} \\
I\left(t_{8}\right)=\left\{p_{h}, p_{b}, p_{f}\right\} & O\left(t_{8}\right)=\left\{p_{l}\right\} \\
I\left(t_{9}\right)=\left\{p_{l}\right\} & O\left(t_{9}\right)=\left\{p_{h}, p_{c}\right\} \\
I\left(t_{10}\right)=\left\{p_{c}\right\} & O\left(t_{10}\right)=\{0\} \\
\mu^{\prime}\left(p_{a}\right)=\mu\left(p_{a}\right)-\#\left(p_{a}, I\left(t_{2}\right)\right)+\#\left(p_{a}, O\left(t_{2}\right)\right) \\
\mu^{\prime}\left(p_{b}\right)=\mu\left(p_{b}\right)-\#\left(p_{b}, I\left(t_{5}\right)\right)+\#\left(p_{b}, O\left(t_{6}\right)\right) \\
\mu^{\prime}\left(p_{b}\right)=\mu\left(p_{b}\right)-\#\left(p_{b}, I\left(t_{3}\right)\right)+\#\left(p_{a}, O\left(t_{8}\right)\right) \\
\mu^{\prime}\left(p_{c}\right)=\mu\left(p_{c}\right)-\#\left(p_{c}, I\left(t_{7}\right)\right)+\#\left(p_{c}, O\left(t_{10}\right)\right) \\
\mu^{\prime}\left(p_{c}\right)=\mu\left(p_{c}\right)-\#\left(p_{c}, I\left(t_{9}\right)\right)+\#\left(p_{c}, O\left(t_{10}\right)\right) \\
\mu^{\prime}\left(p_{d}\right)=\mu\left(p_{d}\right)-\#\left(p_{d}, I\left(t_{2}\right)\right)+\#\left(p_{d}, O\left(t_{3}\right)\right) \\
\mu^{\prime}\left(p_{d}\right)=\mu\left(p_{d}\right)-\#\left(p_{d}, I\left(t_{4}\right)\right)+\#\left(p_{d}, O\left(t_{5}\right)\right)
\end{array}
$$

Граф мережі Петрі, який еквівалентний множину умов:

представленій у додатку структурі C наведений на рисунку 2.

Для формалізації опису функціонування системи метрологічного обслуговування засобів вимірювального контролю параметрів зразків ОВТ мережею Петрі представимо зазначену систему наступним чином: система складається з трьох підсистем $M_{1}, M_{2}, M_{3}$ які відповідають за виконання робіт з метрологічного обслуговування різного рівня складності та підсистеми управління $F$ яка впливає на підсистеми $M_{1}$, $M_{2}, M_{3}$ та формує заявки на виконання метрологічних робіт в залежності від зовнішніх сигналів $S$, що надходять до підсистеми F. Заявки на проведення метрологічних робіт обробляються підсистемою $F$ та в залежності від складності робіт, які необхідно провести, надсилаються відповідно в підсистеми $M_{1}, M_{2}$ або $M_{3}$. Зазначена система буде мати наступну а) зовнішній сигнал $S$ надійшов до підсистеми $F$ та чекає на обробку;

b) сигнал оброблений підсистемою $F$, відправлена заявка на проведення метрологічних робіт підсистемам $M_{1}, M_{2}$ або $\mathrm{M}_{3}$;

c) заявки виконані;

d) підсистема $M_{1}$ очікує на заявку;

е) підсистема $M_{2}$ очікує на заявку;

f) підсистема $M_{3}$ очікує на заявку;

g) підсистема $F$ очікує сигнал $S$;

h) сигнал $S$ формується;

i) підсистема $M_{1}$ знаходиться під впливом підсистеми F;

ј) підсистема $M_{2}$ знаходиться під впливом підсистеми F;

k) підсистема $M_{3}$ знаходиться під впливом підсистеми $F$;

I) підсистема $F$ знаходиться під впливом сигналу S. 


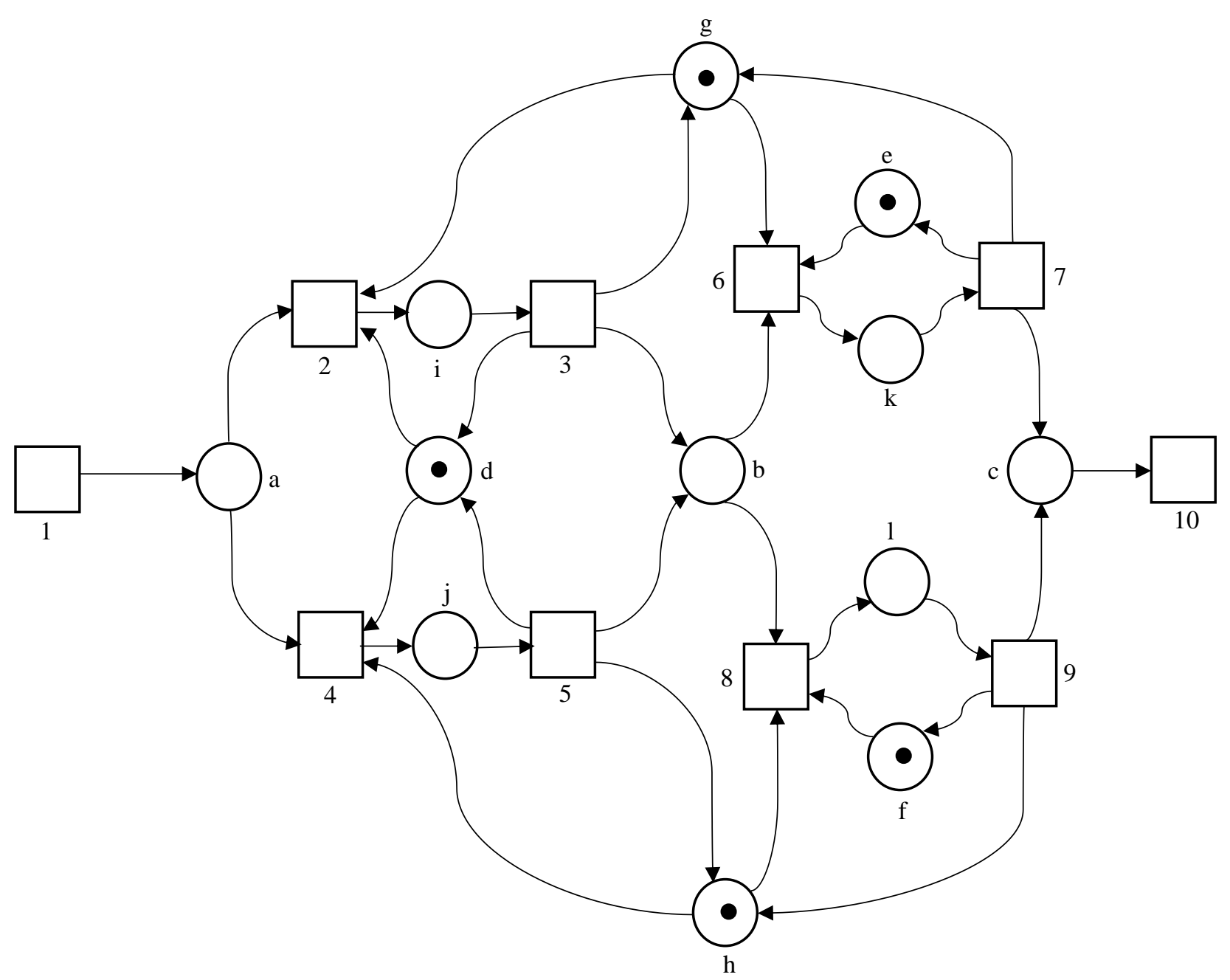

Рисунок 2 - Мережа Петрі для моделювання функціонування системи метрологічного обслуговування засобів вимірювального контролю параметрів зразків ОВТ

При цьому множина подій буде наступною:

1. Надходження сигналу $S$;

2. Підсистема $F$ починає обробку заявки для підсистеми $M_{1}$;

3. Підсистема $M_{1}$ завершила виконання заявки;

4. Підсистема $F$ починає обробку заявки для підсистеми $M_{2}$;

5. Підсистема $M_{2}$ завершила виконання заявки;

6. Підсистема $F$ починає обробку заявки для підсистеми $M_{3}$;

7. Підсистема $M_{3}$ завершила виконання заявки;
8. Підсистеми $M_{1}, M_{2}, M_{3}$ звітують про виконання заявок в підсистему $F$;

9. Підсистема $F$ обробляє звіти від підсистем $M_{1}, M_{2}, M_{3}$;

Приймається рішення щодо виконання системою сигналу $S$, формуються узагальнені дані за результатами роботи підсистем $M_{1}$, $M_{2}, M_{3}$.

Перед- та постумови кожної події в представленій мережі Петрі для моделювання функціонування системи метрологічного обслуговування засобів вимірювального контролю параметрів зразків ОВТ викладені в таблиці 1. 


\begin{tabular}{|c|c|c|}
\hline \multicolumn{2}{|c|}{ Таблиця 1- Перед- та постумови імітаційної моделі } \\
\hline Події & Передумови & Постумови \\
\hline 1 & немає & $\mathrm{i}$ \\
\hline 2 & $\mathrm{a}, \mathrm{g}, \mathrm{d}$ & $\mathrm{g}, \mathrm{d}, \mathrm{b}$ \\
\hline 3 & $\mathrm{i}$ & $\mathrm{j}$ \\
\hline 4 & $\mathrm{a}, \mathrm{h}, \mathrm{g}$ & $\mathrm{b}, \mathrm{h}, \mathrm{g}$ \\
\hline 5 & $\mathrm{j}$ & $\mathrm{k}$ \\
\hline 6 & $\mathrm{~b}, \mathrm{~g}, \mathrm{e}$ & $\mathrm{c}, \mathrm{g}, \mathrm{e}$ \\
\hline 7 & $\mathrm{k}$ & $\mathrm{l}$ \\
\hline 8 & $\mathrm{~b}, \mathrm{f}, \mathrm{h}$ & $\mathrm{c}, \mathrm{f}, \mathrm{h}$ \\
\hline 9 & $\mathrm{l}$ & немає \\
\hline 10 & $\mathrm{c}$ & \\
\hline
\end{tabular}

Виконання запропонованої мережі Петрі для моделювання функціонування системи метрологічного обслуговування засобів вимірювального контролю зразків ОВТ (або поведінка системи, що моделюється) розглядається як послідовність дискретних подій. Порядок виникнення подій $є$ одним 3 можливих, що допускається основною структурою мережі Петрі побудованої для моделювання. Це призводить до очевидної недетермінованості у виконанні мережі Петрі. Якщо в будь який момент часу дозволено більше одного переходу, то будь

\section{Висновки}

В статті обгрунтовано розроблену імітаційну модель функціонування системи метрологічного обслуговування засобів вимірювального контролю параметрів зразків ОВТ на основі мереж Петрі, яка дозволяє проводити імітаційне моделювання функціонування системи з різними параметрами та структурою. Розроблена імітаційна модель дозволяє моделювати процеси функціонування системи метрологічного обслуговування використовуючи модельний час, який може який з декількох можливих переходів може стати "наступним" що запуститься. Вибір переходу, що запускатиметься здійснюється недетермінованим чином, тобто випадково. Ця особливість мережі Петрі відображає той факт, що при функціонуванні системи, що моделюється, в реальному житті, де декілька дій відбувається одночасно, порядок виникнення подій - не однозначний, скоріше може виникнути будь яка 3 множин послідовностей подій. Проте частковий порядок виникнення подій - єдиний.

бути еквівалентним необхідному проміжку реального часу.

Разом 3 тим імітаційна модель функціонування системи метрологічного обслуговування засобів вимірювального контролю параметрів зразків ОВТ дозволяє визначити раціональний склад системи метрологічного обслуговування, раціональні варіанти ії функціонування за отриманими фактичними значеннями показників ефективності.

Імітаційна модель функціонування системи метрологічного обслуговування 
засобів вимірювального контролю параметрів зразків ОВТ може в подальшому використовуватись як інструмент для побудови та аналізу функціонування перспективних систем метрологічного обслуговування з різними параметрами та рівня ієрархії, а також для моделювання функціонування подібних за структурою систем забезпечення.

\title{
Список використаних джерел
}

1. Гаврилов А.Б., Ніколенко В.В., Рондін Ю.П. Методологія системного підходу при розробці моделі організації метрологічного забезпечення Збройних Сил України в умовах реформування і на перспективу. Системи озброєння і військова техніка, Харків, ХУПС ім. І. Кожедуба, 2007, № 2(10), с.39-43.

2. Войтенко С.С. Математическая модель функциональной готовности системы метрологического обслуживания средств измерительной техники. Збірник наукових праць Харківського університету Повітряних Сил, Харків, ХУПС ім. І. Кожедуба, 2011, № 3(29), с.205-207.

3. Ігнаткін В. У. Моделювання процесів метрологічного обслуговування засобів вимірювання. Науковий журнал "Вестник двигателестроения", Запоріжжя, ЗНТУ, 2014, № 1, С. 161-167.

4. Півнєв Д.А., Герасимов С.В., Подорожняк А.О. Математична модель повірки (калібрування) і ремонту засобів вимірювальної техніки в місцях дислокації військових підрозділів. Системи озброєння і військова техніка, Харків, ХУПС ім. І. Кожедуба, 2010, № 4(24), С. 151-154.

5. Литвиненко В.А. Деякі питання моделювання процесу експлуатації i метрологічного обслуговування засобів вимірювальної техніки при оптимізації метрологічного контролю. Науковий журнал “Математичне моделювання", Дніпродзержинськ, 2012, № 1, с. 71-75.

6. Mishchenko V. I., Kravtsov A. N. \& Mamleev T. F. (2021). A Semi-Markov Model of the Functioning of Redundant Measuring Instruments Relative to the Frequency of Verification. Measurement Techniques, 2021, Vol. 64, № 4, p. 289-295, DOI: 10.1007/s11018-021-01931-3

7. Дж. Питерсон Теория сетей Петри и моделирование систем. Москва:, Издательство “Мир”, 1984 г, 264 с.

8. Лескин А.А., Мальцев П.А., Спиридонов А.М. Сети Петри в моделировании и управлении, Ленинград, Издательство “Наука", 1989 г, 133 с.

9. Котов В.Е. Сети Петри. Москва, Издательство “Наука”, 1984 г, 158 с.

\section{Имитационная модель функционирования системы метрологического обслуживания средств измерений параметров образцов вооружения и военной техники на основе сетей Петри}

\footnotetext{
Андрей Дядечко * 1 А

* Corresponding author: ${ }^{1}$ адъюнкт кафедры технического обеспечения, e-mail: andrewvvs@gmail.com, ORCID: 0000-0003-0191-8326

А Национальный университет обороны Украины имени Ивана Черняховского, Киев, Украина
}

\begin{abstract}
Аннотация
На сегодняшний день, в условиях интенсивного развития вооружения и военной техники, средств контроля его параметров, информационных и цифровых технологий и в условиях поэтапного внедрения стандартов НАТО в Вооруженных Силах Украины, одной из приоритетных задач по развитию Вооруженных Сил Украины является создание эффективных
\end{abstract}


систем обеспечения образцов вооружения, к которым относится система метрологического обслуживания средств измерительного контроля их параметров.

Решение такой задачи аналитическим путем является, как правило, сложным, а в ряде случаев по существу невозможно. Как следствие, налицо большое количество взаимных связей как между элементами системы, так и между разнородными средствами измерительного контроля параметров внутри каждого элемента.

Проанализировать и получить информацию о структуре и динамическом поведении системы, оценить ее и выработать предложения по ее усовершенствованию или изменению позволяют известные методы имитационного моделирования.

В связи с этим для решения задач такого вида в статье предложено использовать теорию сетей Петри для имитационного моделирования функционирования системы метрологического обслуживания средств измерительного контроля параметров образцов вооружения и военной техники.

Ключевые слова: метрологическое обслуживание, имитационное моделирование, сети Петри.

\title{
A simulation model of the functioning of measuring instruments metrological maintenance system for weapons and military equipment parameters control based on Petri nets
}

\author{
Andrii Diadechko *1 A \\ * Corresponding author: ${ }^{1}$ PhD student Department of Technical Support, e-mail: andrewvvs@gmail.com, ORCID: 0000-0003-0191-8326 \\ A National Defence University of Ukraine named after Ivan Cherniachovskyi, Kyiv, Ukraine
}

\begin{abstract}
Today, in the context of the weapons and military equipment intensive development, means of monitoring its parameters, information and digital technologies, and in the context of the phased NATO standards implementation in the Ukraine Armed Forces, one of the priority tasks for the development of Ukraine Armed Forces is the creation of effective systems for ensuring samples weapons, which include the metrological maintenance system of measuring instruments for their parameters control. The solution of such a problem in an analytical way is, as a rule, difficult, and in some cases, it is essentially impossible. As a result, there is a large number of interconnections both between the elements of the system and between heterogeneous means of measuring parameters control within each element. Well-known methods of simulation allow to analyze and obtain information about the structure and dynamic behavior of the system, evaluate it and develop proposals for its improvement or change. In this regard, to solve problems of this type, the article proposes to use the theory of Petri nets for imitating the functioning of the metrological maintenance system of measuring instruments for weapons and military equipment parameters control.
\end{abstract}

Keywords: metrological maintenance, simulation, Petri nets, measuring instruments.

\section{References}

1. Gavrilov A.B., Nikolenko V.V., Rondin Y.P. (2007). Methodology of system approach in developing a model of organization of metrological support of the Armed Forces of Ukraine in the conditions of reform and in the future. Weapons systems and military equipment, Kharkiv, HUPS them. I.
Kozheduba, № 2 (10), P. 39-43.

2. Voitenko S.S. (2011). Mathematical model of functional readiness of the system of metrological maintenance of measuring equipment. Collection of scientific works of Kharkiv University of the Air Force, Kharkiv, HUPS them. I. Kozheduba, № 3 (29), Pp.205- 
207.

3. Ignatkin V.V. (2014). Modeling of metrological maintenance of measuring instruments. Scientific Journal "Bulletin of Engine Building", Zaporozhye, ZNTU, № 1, P. 161167.

4. Pivnev D.A., Gerasimov S.V., Podorozhnyak A.O. (2010). Mathematical model of verification (calibration) and repair of measuring equipment in the places of deployment of military units. Weapons systems and military equipment, Kharkiv, HUPS them. I. Kozheduba, № 4 (24), Pp. 151154.

5. Litvinenko V.A. (2012). Some issues of modeling the process of operation and metrological maintenance of measuring equipment in the optimization of metrological control. Scientific Journal "Mathematical Modeling", Dniprodzerzhynsk, № 1, P. 71-75.

6. Mishchenko V.I., Kravtsov A.N. \& Mamleev T.F. (2021). A Semi-Markov Model of the Functioning of Redundant Measuring Instruments Relative to the Frequency of Verification. Measurement Techniques, 2021, Vol. 64, № 4, P. 289-295, DOI: 10.1007/s11018-021-01931-3

7. Peterson J. Petri network theory and systems modeling. Moscow: Mir Publishing House, 1984, $264 \mathrm{p}$.

8. Leskin A.A., Maltsev P.A., Spiridonov A.M. Petri nets in modeling and control, Leningrad, Nauka Publishing House, 1989, 133 p.

9. Kotov V.E. Remember Petri. Moscow, Nauka Publishing House, 1984, 158 p. 